\title{
Development of Multi-Camp Grazing Systems in the Southern Orange Free State, Republic of South Africa
}

\section{L.N. HOWELL}

Highlight: The evolution of multi-camp schemes from nonselective grazing to short duration grazing management on Hillside Ranch in the False Karoo in the Southern Orange Free State, Republic of South Africa, is described. The grazing system resulted in the return and increase of rare and unknown grasses. The conclusion is reached that grazing management with multicamp schemes is useful in counteracting varying climatic conditions and producing a grass cover under adverse growing conditions. In addition it is shown that livestock can produce well under such systems.

The so-called multi-camp strategies of grazing management which have evolved in Southern Africa in the past 15 years have been subjected to much discussion. Management applied in these schemes varies from heavy, relatively nonselective grazing to high intensity, short duration grazing and controlled selective grazing. It also includes a combination of two or more forms at different times of the year. Camp (paddocks of over 25 ha) numbers, even on the same ranch, may be as short as one day. They are generally never longer than two weeks. This flexible approach to management causes rest periods to differ in length according to the number of camps and the way in which they are handled. Rest periods are, however, seldom, if ever, shorter than 6 weeks.

Whatever the number of camps and the way they are used, the common objective of most multi-camp schemes is the steady optimum (not maximum) production of meat and/or wool per hectare and not necessarily per animal-though this too may be attained.

In arid and semiarid areas, however, degeneration of the veld (range) is widespread. The most important goal of multi-camp schemes in these parts is range rehabilitation. This improvement should lead to higher production.

The purpose of this paper is to summarize and record our experience and the benefits received from multi-camp grazing management on our ranch "Hillside," Springfontein, Orange Free State, South Africa, during the period 1961 to 1977.

\footnotetext{
The author is a rancher, Hillside Ranch, Springfontein, Orange Free State, Republic of South Africa.

The author would like to thank the following scicntists in South Africa, Rhodesia, Australia, the U.S.A. and France without whose advice, assistance or interest in large or small ways veld management on Hillside Ranch would not have developed as it has. "My special thanks go first to J.P.H. Acocks, the late Dr. Marguerite Henrici, Dr. J. Ebersohn and Mr. A. Savory, then to Dr. F. Morely, Dr. H. Gordon, Prof. H. Heady, Prof B.R. Roberts, Dr. J.C. Mostert, Prof J.D. Scott, Dr. P. Roux, Mr. A. Fisher, Mr. S.W. Bosman, Mr. L. Vorster, and Mons. Andre Voisin.

My appreciative thanks are due to my fellow farmers here, in Rhodesia, France (the late Andre Voisin again) and Australia (John Watson). Without their practical advice, observations, encourager.ent and assistance at all times I would have suffeed more setbacks than I did during the evolution of multi-camp strategies. I am also grateful for being kept informed on the basic research which has been. and is being. done in many countries besides my own by Departments of Agriculture and at Universities."

Manuscript received August 12, 1977.
}

\section{Description of Environment}

Hillside Ranch is approximately 6,000 hectares in extent, about twice the size of the average ranch in the district. Wool farming with merino sheep is the main industry of the area, with a few, small pedigree herds of either dairy or beef cattle as a sideline on suitable farms.

Soils

The soils around Springfontein are briefly:

Group 1. Red soils derived from the shales of the Beaufort series.

Group 2. Red dolerite soils, mainly of the Shortlands and Valsrivier forms.

Group 3. Yellow-brown soils derived from shales and sandstones of the Beaufort series.

Group 4. Soils of mixed origin of the Oakleaf and Bonheim forms in the low-lying areas.

Hillside Ranch lies on the watershed of the Orange River; soils belonging to groups 2,3 , and 4 are found on the northern side of the farm, while groups 1,2 , and 4 comprise the southern area. The country tends to be hilly with fairly gentle slopes and shallow underground waters in many vleis (low-lying areas which were probably originally marshes) on most farms, though there are few on Hillside.

At some stage of settlement in the past century, many vleis have been ploughed for lucerne (alfalfa) or cash crops. This has lowered the water table. Abandonment of such lands (paddocks) on the less productive soils has resulted in sheet and other kinds of erosion. This has hastened the deterioration of the veld.

\section{Vegetation}

Springfontein falls into the southern variation of the dry Cymbopogon-Themeda veld which has degenerated into false karoo (Bennie 1975). The measure of its deterioration can be gauged from the remarks of early travellers and old transport drivers. Only a century ago the vleis and deeper soils supported grass so tall that transport drivers "tied bells on their oxen's horns" when they "outspanned" to find the cattle more easily in the morning. Today this type of veld has completely disappeared. Bitterbush (Chrysocoma tenuifolia), bare areas and dongas (gullies) have taken its place.

\section{Climate}

Rainfall averages $440 \mathrm{~mm}$ with the greatest amount coming in February and March though rain can fall in any month. Snow occasionally falls in winter. Frosts usually start in April with temperatures remaining low until the end of September. Very heavy frosts - up to $9^{\circ} \mathrm{C}$ can also occur throughout the winter and even into October and November. The irregularity of the 
climate has its effect on the deteriorated false karoo veld (grassy range which has been invaded by small karroid shrubs from the true karoo of the Cape Province). Farmers generally describe a season as a "grass year" or a "bush year." These descriptions are used because rains falling mainly between October and March favour grass growth. Those occurring from March to September encourage shrubs (Chippendal 1955). Droughts, the effects of which have been aggravated by the disappearance of grass cover and the general deterioration of the veld, are fairly common. From diaries kept on Hillside Ranch, it appears as though $7.5 \mathrm{~cm}$ of rain are required on most farms today to achieve the growth that $2.5 \mathrm{~cm}$ gave prior to World War I. When droughts are combined wth a cycle of "bush rain" years, rehabilitation of grass becomes difficult.

An analysis of how and when rains fell accompanied by farmers' general descriptions of the seasons in the past 16 years is shown in Table 1. The comments on the veld's response have been taken from the rainfall record book on Hillside where descriptions are entered annually.

\section{History of Grazing Management}

Continuous sheep grazing with a few camps being rested occasionally for special purposes such a lambing or weaning was the practice on Hillside from 1908 to 1945 . Highly selective grazing took place from 1945 to 1950 when sheep numbers, although conservative by district standards, were reduced in half to one sheep on 2 ha in an endeavour to combat the continued deterioration of the veld. Five years' absence from the ranch during World War II enabled me to recognise the degradation on my return in a way I would not otherwise have done. With the planning of the ranch under the 1948 Soil Conservation Act, a recommended three-camp grazing scheme carrying 600 ewes or 750 wethers per 1,000 ha was applied after 1950. Multi-camp rotations started to replace the recommended system in 1961 because the latter appeared to have failed.

This failure was manifest in two ways. The sheep did not thrive nor produce as well as they had under light, continuous selective grazing unless stocking was so low that financial returns would have been uneconomic in the smallest recession. Secondly, the veld became patchy due to selective grazing by area. It ranged from capped (bare sunbaked) ground to rank ungrazed grass. The only obvious increase to the eye was the continued invasion of the unpalatable bitterbush.

On other farms on varying veld types and in differing rainfall regions, a few keen conservation-conscious pioneer farmers tried to combat similar problems. For example, in this district of the false karoo, a farmer started putting all his sheep into one of his five camps at a time to prune down his karroid-type veld thoroughly for a shorter period than had ever been recommended. The rests after grazing depended on veld condition and

Table 1 Precipitation received at Hillside Ranch during period discussed in this paper and ranchers' views of growth conditions. ${ }^{1}$

\begin{tabular}{|c|c|c|c|c|}
\hline \multirow[b]{2}{*}{ Year } & \multicolumn{3}{|c|}{ Precipition (mm) } & \multirow[b]{2}{*}{ Ranchers' views } \\
\hline & Oct-Feb. & March-Sept. & Total & \\
\hline $62-63$ & 330 & 251 & 581 & Above-average good year with summer rains followed by good autumn rains. Grass year. \\
\hline '63-'64 & 202 & 287 & 289 & Good spring rains petered out into drought with late brush rains. \\
\hline '64-'65 & 175 & 162 & 337 & Drought with bush rains. \\
\hline '65-'66 & 237 & 37 & 274 & Strange grass year. Spring drought 12 inches. Jan. 20-Feb. 20. Drought declared again June. \\
\hline ‘66-67 & 250 & 287 & 537 & Grass about, but rain favoured bush. \\
\hline$‘ 67-‘ 68$ & 151 & 187 & 338 & Very poor season. Bush rains. \\
\hline ‘68-‘69 & 201 & 202 & 403 & Bush rain year. \\
\hline ‘69-70 & 187 & 101 & 288 & Very bad drought with bush recovering a little. \\
\hline ‘70-771 & 325 & 152 & 377 & Grass year but veld recovered poorly after drought. \\
\hline$\cdot 71-72$ & 425 & 162 & 587 & Grass year, but good autumn rains improved bush. \\
\hline '72-'73 & 118 & 200 & 318 & Drought with bush rain which helped matters. \\
\hline '73-‘74 & 602 & 391 & 993 & Fantastic rains with veld being damaged with "wet feet" while trying to recover. \\
\hline '74-'75 & 225 & 125 & 350 & Good spring petered into dry season. Grass about from last year. \\
\hline '75-'76 & 442 & 312 & 754 & $\begin{array}{l}\text { Excessive rains. Grass and bush again killed by "wet feet." Grass year but good autumn rains } \\
\text { helped bush. }\end{array}$ \\
\hline '76-July, '77 & 182 & 130 & 312 & $\begin{array}{l}\text { Dry year with very dry autumn. However, veld and stock much healthier than in previous } 3 \\
\text { years. Seedlings everywhere making up for losses from wet feet. Water table still high. Big } \\
\text { improvement in grass species everywhere on Hillside. Much pioneer grass in district. }\end{array}$ \\
\hline Average & 1962-1977 & & 449.2. & Two excessively high rainfall years have brought average up to about normal over 15 years. \\
\hline
\end{tabular}


rainfall as the sheep moved from camp to camp. In the karroid Danthonia Mountain veld of the Sneeuwberg in the Cape Province, another rancher grazed his "suurpol" (Danthonia disticha) heavily while it was still palatable after he had burned his veld to eliminate invading shrubs. This gave this poorer type grazing grass a setback and reduced its competition for water and light with the better grasses during the subsequent long rest.

Fencing their ranches into small camps for better grazing control and implementation of a more rapid rotational grazing scheme was the policy of various other conservationists. They found the higher stock numbers they were able to carry improved the veld and offset the intial cost of fencing and watering handsomely.

\section{Experimental Nonselective Grazing}

Based on our experience, on that of these ranchers, on information obtained from Tukulu Ranch near Alice, Cape Province (Henrici 1940), and encouraged by a few government pasture spcialists led by the Botanical Survey Officer, John Acocks, we began what may be termed the experimental stage of nonselective grazing (NSG) in 1961. NSG on Hillside Ranch, at that time, was based on the principle of " as many stock as possible on as little veld as possible for as short time as possible followed by enough rest to enable the veld to recover completely.'

With relatively minor changes we adhered to the basic fixed rest and grazing periods of the three-camp system. But cutting each large camp into four sub-camps, it was possible to arrange "a rotation within a rotation.'

After trial and experiment as to the best length of the grazing period and rest, we settled for a " 2 weeks on, 6 weeks off" scheme during the basic 4-months grazing period of the original large camp. This meant that each sub-camp was grazed for 2 weeks and rested for 6 , during the original large camp's grazing period in addition to receiving its usual four months' rest.

Under this method it was found possible to increase numbers and financial returns without any apparent deleterious effect on the veld (Fig. 1). To given an example, in one 1,200-ha block cut into 12 sub-camps from the original three 400 -ha camps, the sheep were increased steadily from 600 to 2,100 . They remained at that number until the last 9 months of the 2-year 1964-1966 drought. At the end of the drought, the area was still carrying 760 sheep in contrast to the 600 previously run. While initially the sheep did not produce as much wool $-4.54 \mathrm{~kg}$ per wether instead of $5.4-5.9 \mathrm{~kg}$ depending on the type of season-their production steadily improved as they became accustomed to the system. Lambs particularly showed no signs of setback. In fact, when the critical 1968-1971 drought broke and the sheep were scattered to take advantage of the first green growth, groups of all ages were found congregating in the corners of camps, indicating that they were unhappy in small flocks. They were gathered together again in large flocks and moved daily through the paddocks until sufficient growth enabled them to stay longer in camps without damaging the newlysprouted veld. Their fertility was not affected at any time, with over a $90 \%$ lamb crop, which is high for merinos. Cattle fertility was also high, going up to $98 \%$ in good seasons.

The 1964-1966 drought, however, confirmed our belief that the basic fixed rests of the three-camp system, even when reinforced by the " 2 weeks on, 6 weeks off" scheme, were too short for the veld to carry increased numbers for long periods when rains did not fall for months. In 1966, therefore, a change was made to what may be called "flexible" NSG.

\section{Flexible Nonselective Grazing}

Each flock (cattle usually ran in herds with them) was as far as possible, allocated to 16 sub-camps. These were grazed for 2 weeks (or less depending on the condition of the veld and the amount of rain during the rest period) one after another. In a drought all 16 camps would be used. In a normal year perhaps only 12 would be grazed while 4 rested for a year. In an above-average rainfall year, as few as 8 might be used.

To prevent the excessive fluctuation of stock such as was experienced under experimental NSG, the size of the flock was

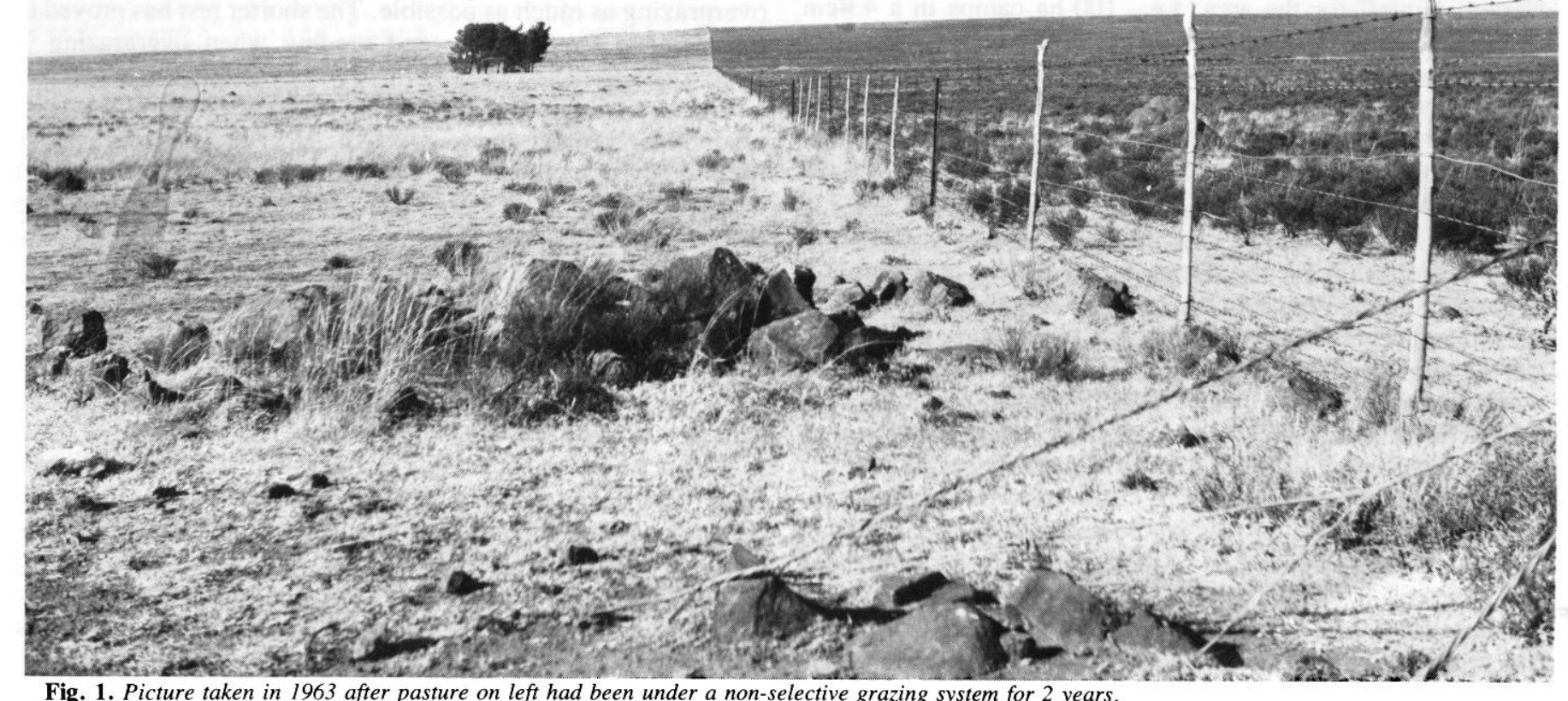

Fig. 1. Picture taken in 1963 after pasture on left had been under a non-selective grazing system for 2 years. 
determined by the number of sheep units (cattle are regarded as 6 sheep units) that could be carried in good condition in 12 camps only. This gave greater protection against drought and steadier financial returns, espcially in the severe recession in wool prices in the late 1960's and the drop in cattle prices locally. It should be mentioned here that all fencing and watering of small camps, which generally averaged 50 ha so as to keep flocks and herds down to a manageable size, was paid for from profits only and not from capital. Even the original capital outlay was recovered with interest from profits.

At this time, Mr. John Acocks, Botanical Survey Officer for South Africa, who had originally suggested the lines along which we should experiment, enunciated four principles and two rules for NSG which should be followed in the karoo and the sweet grassveld (veld which can be grazed throughout the entire year without supplementary feeding save phosphate protein (urea) blocks, which build up the microflora of the stomach of ruminants enabling them to digest dry grass more easily). Sour veld in South Africa is grassveld in high rainfall regions which becomes so unpalatable and indigestible - even with blocks that farmers have to resort to planting green grazing for their stock. Their stocking rates are, therefore, dictated by the amount of arable land they can use during winter).

The principles were: (1) The grazing period must be so short that even the most palatable and scarce plants are not exhausted by being grazed too often. (2) The minimum rest period must be long enough to allow even the most scarce and palatable plants to restore their root reserves. (3) Where veld is not in climax condition (that is, its pristine state before white settlers entered any district) the minimum rest period must be long enough to allow the best and most heavily grazed plants to seed no matter how few they are. (4) Enough animals must be put in a camp so that during the short grazing period they will graze all grazable species to a greater or lesser degree. The purpose of this heavy grazing is to reduce competition from the less palatable and weedy plants.

The two rules were: First, a full year's rest should be given to allow the palatable plants to grow out and produce some seed and as much palatable grazing as possible. If this is done, a rule-of-thumb stocking density (not stocking rate) for a camp should be in the region of 1 sheep per ha per $2.5 \mathrm{~cm}$ of annual average rainfall for the area, i.e., 100-ha camps in a $43-\mathrm{cm}$ rainfall belt would have a stocking density of 1,700 sheep units while being grazing, but the total stocking rate over the 16 camps allocated to the flock or herd would be 1,700 sheep units on 1,600 ha. Second, no rotational grazing scheme should be started until good rains had fallen in a growing season.

At the NSG Conference held at Hillside, Springfontein, in July, 1968 , by a majority vote the first rule was discarded as being too difficult for the farmer to implement in practice. It might also be dangerous in the hands of a farmer who exploits the soil and vegetational resources. It was suggested instead that that the number of sheep running on the area now fenced into 16 camps should be run immediately as one flock. Numbers were only to be increased slowly as rest being given the other camps produced sufficient forage. This meant in effect that the first few camps might well only carry the flock for a few days, but that the length of the grazing periods would increase up to 2 weeks in due course. Stock could then be increased when the whole area was carrying its original quota easily.

After the NSG Conference, however, the following questions appeared to require answers; "What was giving us our returns? Was it the nonselective grazing aspect? Was it the short grazing period? Was it the longer rests? Or, was it a combination of all three?"'

\section{Short Duration Grazing (SDG)}

When rain came in the spring of 1968 , one flock was moved twice a week, one weekly, and the third every 2 weeks.

Within 6 weeks the results became obvious. The veld recovered much faster in the rapid rotation and was ready for regrazing within the approximately 2 -month rest period which was all 16 camps allowed. All flocks were immediately switched to the shortest grazing period in the summer when rain was good, the weather hot, and the veld growing fast. For ease of management, the stock stayed 3 days in one camp and 4 in the next, the period of grazing being reversed in the following mund.

Stay was increased to a week when the veld was growing slowly or was almost dormant in autumn-a critical time of year when veld should not be cut too short. The "nonselective" grazing aspect received attention in winter when the grazing period was extended to 2 weeks with the consequent longer rest. This, then, is the short duration system (SDG) which has been used very flexibly indeed on Hillside Ranch during the past 9 years.

\section{Effect of Multi-camp Schemes and Short Duration Grazing}

With the change to SDG there was an alteration in the approach to rehabilitation. The emphasis shifted from the principle of nonselective grazing all the time with long rests for reclamation to the principle of improving soil surface for easier rehabilitation.

The quicker and more constant passage of the stock (sheep and cattle) through all camps has encouraged more littler lying over the whole area in summer instead of relatively few camps, as in NSG in normal and above-average rainfall years. Further, since all stock tend to concentrate on poorly covered, capped (hard sun-baked) surfaces, the ground is chipped by their feet more often between rains. This leads to better infiltration of water and casier germination of seeds.

The shorter grazing period has become a tool to prevent overgrazing as much as possible. The shorter rest has proved to be adequate for recovery and seeding when overgrazing is largely counteracted in growing periods in summer.

The use of the 2-week grazing period in winter has been retained to protect the evergreen and winter green grasses (previously unknown in the district or of very low occurrence) during their important growing season, which, we assume, due to our excessive cold may be slower than summer-growing grasses; to eliminate competition from such unpalatable grasses as tend not to go into senescence when ungrazed; and to keep the palatable plants pruned and vigorous.

Our chief barometer of veld improvement on Hillside has been the increase of grass cover everywhere with a resultant heavier carrying capacity of cattle on Hillside Ranch. Our second has been the behaviour of the valuable evergreen fodder grass (Tetrachne dregei). It has reappeared from completely dormant crown in many areas, including bare capped surfaces where none was previously observed. The increase in seedling establishment has been the measurement of its returning vigour. The grass is now so widespread it seems possible that it was once dominant or co-dominant with rooigrass (Themeda triandra) on suitable sites. 
Table 2. Important species occuring on the Hillside Ranch in South Africa.

\begin{tabular}{|c|c|c|c|c|}
\hline Species & Past occurrence & Present occurrence & Value & Past and present habitats \\
\hline
\end{tabular}

Grasses

Fingeruthia sesleriaformis Rare Increasing rapidly

Almost ever green fodder. Vleis only. Now in hills or where water flows slowly due to increased cover.

Helichtotrichon turgidum

Unknown until area receives Increasing rapidly 100-200 mm more than Springfontein

Hordeum capense

Ditto Increasing rapidly

\section{Koeleria cristata}

Miscanthidium sorgum

Rare

Ditto

Panicum staphf.

Low

Plentiful

Pennisetum sphacelatum

Rare

Plentiful in suitable sites

\section{Themeda triandra}

Tetrachne dregii
Very rare

Increasing rapidly

Fairly common

Increasing rapidly
Winter green fodder.

Vleis, slopes, and hills where water is held up by increased cover. Intermingles with summer grasses.

Ditto. Also described in Grasses and Pastures as trial as hay."

Winter green fodder.

Erosion, but becomes good grazing when heavily grazed under NSG and SDG as it regrows slowly with soft leaves.

Summer, grazing, grass remaining green in dry midsummer.

Vleis, where it also is a pioneer on bare areas.

Vleis where it intermingles with summer grasses.

Originally vleis only where water table high. Now in hills and slopes where water flows slowly.

Thick in vleis, replacing Themeda triandra. Dry slopes and hills. Pioneer on capped areas. Stands up to droughts and "wet feet."

Very heavy carrying capacity Formerly vleis only, now coverring slopes and in hills where water is slowed. Appears it may have been dominant or codominant with Themeda on suitable sites.

"Bread and butter" grass of Formerly only found on good area. soils. Now on slopes and shallow soils.

Evergreen fodder forming Formerly vleis, now everywhere large swards. Heavy carrying where soils are even slightly capacity. or co-dominant with Themeda and Pennisetum on suitable sites.

Shrubs

Originally on all soils, but has
Increasing, but will disappear when grass cover increases under its protection.

Increasing on all soils but tends to disappear when grass very thick.

$$
\text { Aster barbatus }
$$

Rare

Increasing rapidly

Relatively rare. Overgrazing Increasing as a pioneer on

made it appear to be an bare areas. annual.

Rare

Increasing rapidly, especially Very palatable in spring. as a pioneer on bare or thin ground

Gives before-rain early spring grazing. Useful antierosion plant. Deep rooted.

Chrysocoma tenuifolia

Very common

Virtually disappeared

Unpalatable invader. vanished save on thin areas.

Increasing rapidly on shallow Palatable. Useful antierosion soils bush. Heavy seeder.

Largely disappearing. Unpalatable invader.

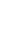
Very palatable, especially Only found under protection of
in winter.
Very palatable, especially Only found under protection of
in winter. Rare bush not driven out by any save very thick grass.

Very palatable, especially in winter. Good sheet erosion Nenas spp.

Rare

Wide spread

Deep soils. Now spreading as pioneer on shallow soils. Disappears in thick grass.

Pentzia spp. 
Table 2 (continued)

\begin{tabular}{|c|c|c|c|c|}
\hline Species & Past occurrence & Present occurrence & Value & st and present habitats \\
\hline Phymaspermum parvifolia & $\begin{array}{l}\text { Relatively rare due to over- } \\
\text { grazing }\end{array}$ & $\begin{array}{l}\text { Increasing rapidly, especially } \\
\text { on shallow soils }\end{array}$ & $\begin{array}{l}\text { Good winter grazing. Pala- } \\
\text { table. Seeds prolifically when } \\
\text { protected from overgrazing }\end{array}$ & $\begin{array}{l}\text { Found in vleis and slopes. Now } \\
\text { taking over on shallow soils. } \\
\text { Tends to disappear in thick grass. }\end{array}$ \\
\hline Polygala virgata & Very rare & Increasing rapidly & $\begin{array}{l}\text { Very palatable sedgelike } \\
\text { plant. }\end{array}$ & $\begin{array}{l}\text { On banks of spruits. Now found } \\
\text { everywhere, especially on shal- } \\
\text { low soils. }\end{array}$ \\
\hline Trichodiadema parvifolia & Rare succulent & Increasing rapidly & $\begin{array}{l}\text { Very palatable and valuable in } \\
\text { in winter and droughts. }\end{array}$ & $\begin{array}{l}\text { Found only under protection of } \\
\text { other plants. Now pioneering on } \\
\text { most soil types except hills. }\end{array}$ \\
\hline Trifolium africanum & Rare annual red clover & Increasing rapidly & $\begin{array}{l}\text { Very palatable. Useful as } \\
\text { pioneer and nitrogen fixer. }\end{array}$ & $\begin{array}{l}\text { Wet places. Now found wherever } \\
\text { grass holds up water flow, } \\
\text { especially on bare areas above } \\
\text { grass. }\end{array}$ \\
\hline
\end{tabular}

The increase of other scarce and valuable summer forage grasses and legumes as well as the appearance of previously unknown winter grasses has been as startling and rewarding as the reappearance of Tetrachne dregei. The value and habitat relations of these plants have been listed in Table 2. As, however, the Southern Orange Free State falls into the false karoo, the reactions of some shrubs and other plants under multicamp strategies has also been recorded in this table.

Increased grass cover has led to camps having to be reduced in size to control the length of the grazing period for the same-sized flocks. The most extreme example is a 28 -ha paddock which was eroding badly. Isolated before NSG to prevent further sheet and donga (gulley) erosion, the paddock used since 1961 has had to be subdivided thus far into one 14-ha and two 7-ha paddocks.

To keep the grass further under control and grazable for sheep, cattle numbers have had to be increased. From a nominal number kept for milk supplies for the house, they have risen to 300 ranching animals for the production of weaners for feeders or directly for sale for slaughter-the quickest and highest return per annum per beast in South Africa. Although there has been a recession in meat prices in 1977 and much larger numbers have had to be sold for slaughter, those sold out of hand to local townsmen have been described as "over fat" or "almost too fat" despite the fact that they received nothing but veld grass while drinking from their mothers. Supplementary blocks have also been kept to the minimum this season due to rising costs.

Due to the rise in cattle, sheep numbers have had to be decreased. Up until 1970 they increased steadily to 900 sheep units on 6,000 ha. With the government's removal of a subsidy on fodder and low railage rates during droughts and with the vastly increased prices of such items as maize and lucerne (alfalfa), overall numbers have been decreased to just over one sheep unit per ha. It is hoped that in this manner no feeding of stock will have to be done during droughts in the future. Numbers will only be raised again when further thickening of the veld cover shows during droughts that present numbers are too conservative.

The reduced number of sheep has produced unexpected bonuses. Wool from Hillside Ranch, despite an $8 \%$ drop in the market, sold for the highest price for any clip in South Africa marketed through East London this season. The top line was typed as a speciality wool for which we had not been breeding deliberately and microned at 18.4 a figure we were told that had not been achieved in East London for fine wool for many years. Despite the fact that sheep with fine wool are supposed to produce less, we averaged $4.53 \mathrm{~kg}$ per sheep, which is slightly above the average for the district on veld alone. Their carcass weights were also outstanding. They compare more favourably with the South Australian merino, a large sheep with very strong wool which has never been imported into South Africa. Body weights sent us by the CSIRO (Australia) showed that our sheep weigh to a kilogram more at the same ages. Fertility is also high for the merino. How much of this is due to breeding and how much to the feed value of our improved veld is difficult to estimate. The Australians used to have a saying that "feeding is $75 \%$ of breeding." In our case the improvement of the veld has gone hand in hand with a change in stud breeders (we breed our own flock rams), so that the situation is by no means clear, but merinos bred from his stud's blood have not given him quite such good results in any other area to which he sells.

Finally, even before the excessive rains of 1973-1975, three poorly developed seasonal springs had become permanent, enabling camps to be further subdivivided without additional watering costs. One of the new seasonal springs which has appeared since 1968 is now having weirs erected near the eye to pump water to the garden. Two additional springs have become virtually permanent, though their sponges will have to become thicker for assured permanency in drought years. The water table has risen in all bore holes, running out of the top of some when rains come in any quantity. There is no record on Hillside of this occurring since 1908, though it may have happened in the latter part of the last century.

To sum up, the years 1961-1977 have shown on Hillside Ranch that grazing management with multicamp schemes has been capable of producing grass cover despite the setbacks that have occurred to certain vegetation types in floods, in recurring droughts and in "bush rain" cycles.

Better still, as ranchers, we have been privileged to enjoy the interest in our veld so vividly described by the late Fseld Marschall J.D. Smuts in his foreword to Grasses and Pastures of South Africa. "Once you take a little trouble to become acquainted with grasses, their attraction and their glory grow on you until at last you surrender completely to their charm. And in Africa, once you leave our deserts, it is grasses and glory all the 
way. At sunrise and sunset on our veld, in Spring and Autumn, when youth and maturity are in command, there is a strange fascination which no pen can describe."

\section{Literature Cited}

Acocks, J.P.H. 1953. Veld types of South Africa Mem. Bot Survey South Africa. No. 28. Government Printer, Pretoria.

Bennie J. 1975. Dep Soil Science, University of the Orange Free State, Bloemfontein. Personal Communication.
Chippendal, Lucy. 1955. The grasses and pastures of South Africa. Edited by D. Meredith, C.N.A. Johannesburg.

Henrici M. 1940. Fodderplants of the Broken Veld Part 11 (Fauresmith District) Sci. Bull. No 213 (Soil and Veld Conserv. Ser. No. 1) Government Printer, Pretoria.

Howell, Denise. 1962. The new look in veld management. Farmer's Weekly Feb. 2, 1962. p. 18-20.

Matthews E.D. 1950. "Tukulu" The Rebirth of a South African Farm. Lovedale Press, Alice, Cape Province. South Africa.

Roux. P.W. 1966. Die uitwerking can seisoensreenval en beweiding op gemende karooveld Proc. Grassveld Soc., South Africa 1: 103-109. 